\title{
Exploring Shankar Pathak's Ideas on Indian Social Policy, Welfare and Social Development
}

\author{
Venkat Pulla \\ Institute for Land Water and Society (ILWS), Charles Sturt University, Wagga Wagga, NSW, 2678, Australia
}

\begin{abstract}
Any discussion around India's Social Policy, Social Welfare and Social Development ought to be laid in the context of India's sixty years of planning history. In this critical essay, I explore the views and treatise of octogenarian Shankar Pathak on social welfare policies and development of the poor in India. In those sixty years of planning, India has certainly made strides, such as producing some billionaires that enter into who's who list compiled by Forbes, alongside its poor making world's record officially included into the top ten poor nations. India's situation can be aptly captured and surmised by borrowing the famous saying of American Political Economist 'doing better but feeling worse' (Wildavsky,1977, pp 105). The current paper examines Pathak's views on social policy, welfare and social development in India and to an extent his views on social work profession in India, that were made available to Indian social work academia through his book (2013) on 'Social Policy Social Welfare and Social Development' brought out during his sojourn in Bangalore and further through a cursory view of his blogs.
\end{abstract}

Keywords Social Policy India, Social Development India, Social Work India

\section{Introduction}

I have spent some 38 years in India and even if I miss reflecting on my innings until my teenage, I vividly remember about my growing awareness of two rather pervasive phenomena in the Indian society i.e. a hierarchical structure and abundance of stark inequalities amongst people. I used to ask my teachers about a generic question: Why? Overtime I studied social work at the Tata Institute of Social Work, in its hay days when late Professor M. S Gore was the Director who taught us social development and social policy. Interactions and teachings in TISS (1975-1977) made me understand that there were two giant obstacles for development in India. Firstly, our social hierarchical structure and secondly the stark inequalities amongst people will stretch the limits of the profession. Historians could see this being an Indian characteristic for centuries. It is this pathological condition that worried the Delhi school of social work academic Shankar Pathak who reworked and updated some of his previous writings originally written in 1979-1987 period and subsequently added his reflections on the current aliments that plague India. The task of reviewing sixty years of official economic and development planning in India from the lens of social work constitutes a review of how good, bad, ugly and pervasive, this commitment has been towards looking after the poorer and vulnerable sections in the Indian society. Many Prime Ministers in India have declared their vision to see that 'poverty, as we see it, will be a thing of the past. Every village will be electrified, assured of clean drinking water and adequate health services. Education will be available to every child' (Rajiv Gandhi 1987, quoted in Pathak, 2013)

\section{Poverty and Social Work}

Pathak nearly all his life analysed the profession's reach and often questioned social work's 'apolitical' stance. In his writings Pathak clearly indicated his yearning for social work and urged us all to take on the role of an 'ideologist and a social actionist'. Pathak, with great admiration relates to a story of a missionary in Travancore, South India and suggested that we cannot see serious work in social justice. Unless we become political missionaries. There is no alternative, he reiterated. (Pathak, 2013)

Pathak wrote further:

'whatever be the phrase- social justice, distributive justice, redistributive justice- the underlying idea is fairness by man to fellow human beings based on the principle of equality - social, political and economic'. It implies undoing the wrongs done to segments of population for decades and even centuries by those who had the power to take the lion's share of all social 
resources including human dignity. It implies compassion, care and concern for the deprived and the exploited' (Pathak, 2013 p.196)

Indian social work history is chunky about social reformers and about the causes that they attempted to deal with in those times. But as we tease those causes it becomes clear that a great number of them actually dealt with poverty. 'While the heritage seems to be the source of inspiration for modern social workers' Pathak, writes, 'who unlike those early leaders like Raja Ram Mohan Roy, M.G.Ranade, and Keshab Chandra Sen, failed to devote any attention to the miseries of the poor, let alone make poverty the main focus of social work' (Pathak, 2013, p 135) Historically social reform and social work in the industrially advances countries of the west originated around the problem of mass poverty, following industrial revolution. Thus social work and social workers retained some kind of an attachment of link with poverty as part of their heritage. Pathak writes:

'As is well known, social reform movement in India had a different beginning. Certainly, the circumstances were not similar. As a result, the social workers in India have not felt it necessary even to maintain a tenuous link with the problem of poverty....If they ( social workers) were concerned with the poor as part of their work, it is because they had no choice about it'(Pathak, 2013, p 135)

Pathak expressed his unhappiness and contempt at the growing corruption, lack of transparency, irresponsible leadership, and opportunist political sloganism, misguided and ill guided ambitions amidst plenty of opportunity to right every wrong in the country called India. But Pathak also saw a ray of hope in the profession of social work but wished that it was able to produce a cadre that could sheppard and lead poverty alleviation. I remember having a follow up conversation with the current president of NAPSW, Professor Sanjay Bhatt on the sidelines of a great National Social Work Congress that he has put up in Ladnun in Rajasthan in October of 2015. We carried forward this quite debatable question: where is contemporary Indian social work heading? Tragically we both were left in much grief to see that it seems to be producing a level of clerical functionaries similar to many western countries, many munims (clerical staff in bureaucracy), that sit and administer programmes handed down from the top. These functionaries seem to be happy they have a job as a result of their degree and happily work with what is handed down as a Programme of development rather than work with people's needs. Social workers seem to talk to people and consult them over programme and methodological changes, but are becoming a breed of workers bereft of ideology social action for social justice. We couldn't agree more with what Pathak wrote earlier:

'If we want to work for social justice, we have to be political missionaries. There is no alternative. We cannot speak like radials and act like conservatives. That would be hypocrisy unlimited. I am actively conscious of the fact that the task is not easy. But a beginning has to be made in all earnestness' (Pathak, 2013, p, 196)

Certainly, these questions that Pathak raised are paradoxical in the context of social work philosophy. Social work has an espoused commitment for equality and justice but the profession does not appear to be sensitive to incidences of injustices committed every day. Be it India, or East Timor, or Australia or United Kingdom, - social work professional remains a silent spectator and even an eyewitness to injustice with limited reach and interventions.

India needs a range of social workers. If I may describe them they would fall under the following categories. social work dreamers and achievers; daring social workers; innovative social workers; those that can work from within the government and bring change; disrupters; those who believe and work on Gandhian lines; social workers who can see the ecological connections and can articulate them; social workers who work for LGBT and human rights areas; social workers who work for civil liberties; social workers who can articulate that all social work is political.

Certainly, we need a live wire brand of academics who have practice interests in social work. There is no other mantra for salvation of social work in India but to start building such cadres of social workers.

\section{Pathak's Approach}

For social work academics that desire a critical appreciation of the more complex economic, public administration and policy phenomena, a sense of time and modern history of India, Pathak re-packed in his last book titled Social Policy, Social Welfare and Social Development (Pathak, 2013), several anecdotal vignettes from his time in social work. Pathak counted over sixty years of Indian's planning and development through a interdisciplinary lens and made his book a must read for anyone who wishes to understand why India is unable to develop or on a more positive note and that the country still has an opportunity to respond to ameliorating its poverty. Shankar Pathak has given sixty years of his thought approximating to the sixty years of planning in this country called India. Shankar Pathak belongs to the era of social workers who gave unto themselves the privilege to critically evaluate the contexts, concerns and the commitments of the state in the area of welfare with the rigour that the questions deserved. Pathak (2013) raises the questions: what is the problem? Who owns the problem? Who ought to own the solutions and the final question are there any policy instruments that can be utilised? Pathak clearly identified government action as residual work resulting in a range of state legislation, law that depended largely on state's fiscal or monetary allocations. To which 
he saw the need to add advocacy, and people's voices as two additional important instruments.

When I use the word advocacy I am talking about the possible role of social work advocacy in India. Certainly, the number of schools of social work has increased in India since advent of formal social work education in India. We also notice thousands of non-state actors that work in the welfare sector, seen as a great opportunity for advocacy. Pathak saw that the definition of the stake holder is skewed in the Indian lingo of planning and ensuring development due to planning function preoccupation with handing down policies that do not seem to match with stakeholder profiles. This is despite of years of post-planning and post decision research in India. Pathak writes:

'The poor have always been a happy hunting ground for the politicians, the reformers and the academicians. This is not surprising. Poverty is good business for some people. Described as the salt of the earth nineteen centuries ago, the poor today are known as the wretched of the earth and as the fourth world' (Pathak, 2013, p, 119)

\section{Do Bureaucrats Hate Poor?}

Interesting fact of history that Pathak revisits in his writings relates to poverty of the Indian people that plays a very major part in both unifying the native population as a community in their struggle against the colonial power and in developing the sense of nationalism among the elite, thus 'since $19^{\text {th }}$ century monarchs and politicians have found it expedient to legitimise their claim to hold power by an appeal to the poor' (Pathak, 2013, p, 130). I am fascinated by his candid but valid observations from his field work days in Rajasthan about how government bureaucrats viewed the poor. Similar to Pathak, are my own observations confirm that most government bureaucrats hate the poor, because they don't know what to do with them. Pathak (2013) says:

“.... Rajasthan gave me plenty of opportunities to observe the deep hostility of the government bureaucracy towards the poor. There are of course, sympathetic and dedicated individuals at all levels of the bureaucracy. But the overall mindset in these circles strikes me as extremely anti-poor' (emphasis supplied by Pathak, 2013, p 200).

In the last 25years for a substantial amount of time I worked in state bureaucracies in Australia, and I can confirm with my own observations that hostility towards the poor cuts across all societies and nations. My observations are qualified by experience of working with teams that work post disaster in communities to get the families and communities recover from the impending effects of disaster. Barring social workers and allied health workers, I have noticed hostility towards the poor as part of the objective culture of bureaucracy.
India's poor, always astonishingly, receive mention when the rest of the citizen elites want to build sky scrapers or beautify the cities. The poor are cleaned out and can be bulldozed and their houses razed in the wake of city development or road widening. These people can be banished to the outskirts of the city. Pathak intrigues at the relationship of the poor with the rest of the population. He finds that the relationship is akin to the concept of metropolitan-satellite relationship. The elites and the well to do are the metropolitan keepers of the urban society that can see the relegated lives of the poor to the untouchable squalors of the cities or rural fringes: essentially built around the edifice of inequality, exploitation and dependence. Pathak defines poverty 'as a failure of a segment of the population to command essential resources of life' (2013, p, 134).

Telangana, Maharashtra, and many other states are witness to farmer suicide. The poor in the rural front have tales and pathetic sagas of farm labour suicides, listlessness and lack of equal opportunities for education and development constantly causing high rates of incidence of internally displaced populations that move from one state to the other in search of livelihood. Pathak, see the manifestation of anti-poor stance of bureaucracy through:

'Pervasive tendencies to blame the victims for their own predicament, poor people are blamed for being lazy, for not sending their children to school, for squandering their money to drink and so on. In the context of drought relief, they were constantly accused (against all evidence of being unwilling to take up employment on relief works' (Pathak, 2013, p200)

Amita Shah, director of Gujarat Institute of Development Research, says, "Poverty reduction programmes must include issues of economic growth, employment generation, socio-spatial equity, environmental sustainability and political stability within a holistic framework" (Shah, A, in Mahapatra, 2011). There is inequality in the efforts made to prevent people from poverty and get them out of it. The numerous poverty alleviation programmes are inadequate and insufficient (Mahapatra, 2011). Poverty is becoming hereditary in India, at least for a sizeable population. That is the conclusion derived from a three-decade tracking of poor households in rural India. A survey by the Chronic Poverty Research Centre (CPRC), an international association of researchers and academicians, claims that those who are chronically poor may pass on poverty to their next generation. What's more, people residing in tribal and forested areas are likely to remain poor forever, fomenting violent conflicts in future. Most of India's forested districts are already dens of Naxalites (Mahapatra, 2011). Of the 29 such programmes studied in the survey, only nine could prevent people from falling into the poverty trap. Thirteen could enable escape from poverty and 16 could alleviate chronic poverty. Shashanka Bhide, a senior fellow of the National Council 
of Applied Economic Research says that a significant proportion of non-poor households may fall into poverty while a large proportion of poor may not manage to escape it (Mahapatra, 2011).

India's population, irrespective of its numbers at any given point of time, will always have nearly two thirds living in appalling conditions, gutters, and squalor. But they will of course run the cities relentlessly from the rural environments or tribal habitats. Politicians occasionally champion their cause but constantly feed on them and only marginal adjustments are advanced to those in poverty. In the table below I will present some select investigations into Chronic Poverty.

\begin{tabular}{|c|c|c|}
\hline Drivers & Maintainers & Interrupters \\
\hline Health Expenditure & Poverty & $\begin{array}{c}\text { Income } \\
\text { diversification }\end{array}$ \\
\hline $\begin{array}{c}\text { High interest } \\
\text { Borrowing }\end{array}$ & Indebtedness & Asset accumulation \\
\hline Crop Failures & Poor healthcare & $\begin{array}{c}\text { Marketable skills/ } \\
\text { linkages }\end{array}$ \\
\hline Natural disasters & $\begin{array}{c}\text { Loss of productive } \\
\text { assets }\end{array}$ & Access to credit \\
\hline $\begin{array}{c}\text { Loss of productive } \\
\text { assets }\end{array}$ & Governance failure & Wage increase \\
\hline Source: Adapted from India Chronic Poverty Report ( 2011) \\
\hline
\end{tabular}

Mahpatra (2011) writes that India's Supreme Court ordered the planning commission to explain the basis of coming up with a percentage of people below-poverty-line (BPL) as being at 36 per cent. The percentage helps the commission decide the direction of development programmes and distribution of food grains under the public distribution system. The apex court's observation came in the wake of a petition filed by nonprofit People's Union for Civil Liberties. The petitioner contended that adequate food grains are not being given to people living below the poverty line. Social workers ought to become familiar with this as this probably will enter into the fundamental rights within the constitution as the Right to Food. The court also challenged the commission's estimates of BPL families. "There cannot be two Indias," said the apex court while describing the country's high economic growth and consistent poverty. "The poverty level is reducing but at a slow pace," (Mahapatra, 2011).

\section{Poverty and Democratic Governance}

I am not sure if there is a commonsense perspective that takes into consideration a normative stake holder analysis before considering planning for poverty alleviation in India. I suggest that such an approach to stakeholder analysis ought to have at least two variables: the interests of the stake holders and if they have any claims and whom do they make these claims? From a social welfare perspective the stake holders ought to be the clients; provider organizations; government structures in India; people advocates; non state actors and broader public. Pathak's observations (2013) suggests

- $\quad$ lack of orchestrated consultation processes

- lack of will to build collaborations with people around what they need

- non adherence to any collaborative production

- $\quad$ prejudice towards the poor in India

- Incapacity of understanding what the core problem is and identifying what sort of policy options are required to deal with it.

Pathak clearly sees that there are many systemic and social obstacles that require attention before poor people's rights and needs become claimable. He indicates that these firstly relate to the capacity in the Indian society and secondly to the willingness to develop programmes of amelioration of the poor. Pathak examines the state governments in West Bengal, and Kerala (Kerala to a lesser degree) where the communists and communist with other progressive group led coalition's ruled for most of the six decades, to argue that the efficacy of their ideology ought to have had some difference in the poverty claims of the people. Indian constitution with its clear directions of principles of state policy allows for such variance such that the willingness of the state can positively be tempered by the ideology, resources, ability to respond to local crisis and to pioneer alternatives for progress and models for other states to follow. Multi-party coalitions including those coalitions arrived through the making of post-election alliances, are now the norm in the states as well as at the centre in India. This means relatively higher support across the board for smaller political parties with a narrower social and geographical focus (Mehta, Shepherd, Bhide, Shah and Kumar, 2011).

A serious consequence of the period of the last thirty years seems to be frequent elections and multiple coalition governments and politicisation of the civil administration. The slogan for tourism in India is "Incredible India' but for the political situation it possibly is 'un-predictable India' lack of respect for verdicts from apex judicial institutions; flagrant flouting of constitutional rights of citizens, revisiting questions to build a mosque or a temple, carving new religions such as lingayatism,, constantly increasing the quotas that exist for backward classes- which they are not asking for but the ruling and oppositional elites create to keep their voters loyal, creating bun fights between the same castes, to let or not to let women into Haji Ali or Sabirimala, , bringing in uniform civil laws that allow all women to have one law- not Muslim law but just one law that allows all women to enjoy one civil procedure in matters regarding divorce and to scrap special statuses to some states such as Jammu and Kashmir and the most distasteful of all- appeasement polices to keep the underdogs faithful. Several of the poorest states have been governed by regional political formations or by a national party that is not in power at the central level. There has also been a strong wave of identity politics among communities trapped in poverty. This has included a rise in the 
prominence of communal issues, formation and split of the 'backward class' vote bank, Dalit assertion and intensified efforts by women to attain political space (Mehta, et al , 2011). This seems to be the 'unpredictable and pathetic India- and there is an incredible task for social work. One needs to sit and figure out how, this despite many introductions of economic reforms, Tribal political elites in the Hindi belt have also successfully distanced themselves from others by demanding their own territories, which in 2000 were carved out of Bihar (Jharkhand), Uttar Pradesh (Uttarakhand) and Madhya Pradesh (Chhattisgarh). A rise in the number of non-party networks of democratic people's movements and civil society activists has been a prominent feature of this era. These have challenged the purpose and process of the paradigm shift, using peaceful and democratic means around issues of livelihoods, agriculture, displacement, disinvestment, the environment and human rights. Some have also been associated with the nationwide and sometimes worldwide networks of anti-globalisation groups (Mehta,et.al ,2011).

It appears that good governance is central to the achievement of the Millennium Development Goals (MDGs), as it provides the 'enabling environment' for the realisation of the MDGs and, in particular, the elimination of poverty from a social work perspective. The critical importance of democratic governance in the developing world was highlighted at the Millennium Summit of 2000, about thirteen years ago where the world's leaders resolved to promote democracy and strengthen the rule of law, as well as respect for all internationally recognised human rights and fundamental freedoms, including the right to development. A consensus was reached which recognised that improving the quality of democratic institutions and processes, and managing the changing roles of the state and civil society in an increasingly globalised world must underpin national efforts to reduce poverty, sustain the environment, and promote human development. As such good governance people's involvement and their inputs into the planning process. From the human rights perspective enjoying freedom from fear and want can only be achieved when we create conditions that guarantee everyone to enjoy his or her economic, social and cultural rights, as well as his or her civil and political rights in society.

In this regard, I am sure the Indian constitution has adequate emphasis that stipulates that everyone has the right to a standard of living adequate for health and well-being of himself and of his family, including food, clothing, housing and medical care and necessary social services, and the right to security in the event of unemployment, sickness, disability, or other lack of livelihood in circumstances beyond his control. The eradication of widespread poverty, including its most persistent forms, and the full enjoyment of economic, social, cultural rights, civil and political rights remain the interrelated goals. These very rights are also expressed as millennium development goals that India ought to be reminded constantly.

It is my firm belief that alleviating poverty is a daunting task to be simply left to government; therefore I suggest that no one section in society is capable of doing anything with poverty. The paranoia in political parties is all about showing some of stewardship in servicing the poor. But political elites that sleaze on poverty and the bureaucrats that programme the political mandates into successive government programmes and the economists that oversee the planning commission processes often are left to be content adjusting the ill-fated poverty line and bumping the 'poor' up or down. Seriously poverty has to be seen as every body's business. It is not largesse thrown at poor or semblance of social responsibility by some business houses. it is quite in order that we do not have a Harvard Management School prescription for a solution for poverty. India has some of the top management schools that produce the managerial mandarins of the future, several that go away to make the rest of the world a better place to live. I believe that some deliberate and sustained dialogue needs to take place between those who can provide good human resources and build an enabling ethos in the society. India needs to find its own answers for its poverty. Brilliant graduates and geniuses with an un-ignited social conscience require opportunities to challenge their skills to find solutions for India's welfare. The stakeholders in poverty alleviation ought to include the poor, the average man on the street, the business houses, the country's top management schools, the ruling elites, social workers and the three tier government agencies to look at an integrated and holistic approach based on inputs from all stakeholders.

How would India's postcard on the MDGs implementation look like? Will it focus on self-reliance, prioritising the goals? Doing MDGs right is actually another way of meeting and strengthening human rights in India. A need to link the agenda of development, human rights and extreme poverty, as well as efforts to empower people living in poverty to participate in decision-making processes on policies that affect them together are certainly required. If India aims to become a peaceful society its social work and welfare agenda ought to create institutional and non-institutional apparatus that is ripe for development and free itself from injustices and human rights abuses. We had the good fortune that a man called Shankar Pathak walked with us for some time in social work and gave us an impetus to think ahead our role in social development in India, not in its corporatisation but in its right deal to the vulnerable peoples and from a rights framework.

\section{Acknowledgments}

I am personally grateful to NAPSWI, India and Professor Sanjai Bhatt for his review and for including an 
earlier version of these thoughts in 2018 Napswi Conference proceedings as a tribute to Professor Pathak

\section{REFERENCES}

[1] Mahapatra, R, (2011) Poverty begets poverty http://www.downtoearth.org.in/content/poverty-begets-pov erty Accessed on 25/05/2013

[2] Mehta,AK, Shepherd,A Bhide, S, Shah, A. and Kumar,A, (2011) India Chronic Poverty Report: Towards solutions and new compacts in a dynamic context,Indian Institute of Public Administration, New Delhi

[3] Pathak, S, (2013), Social Policy Social Welfare and Social Development, Niruta Publications, Bangalore, India

[4] Wildavsky, A, (1977), Doing Better and Feeling Worse: The Political Pathology of Health Policy, Daedalus, Vol. 106, No. 1, pp. 105-123

[5] Published by: The MIT Press on behalf of American Academy of Arts \& Sciences, Accessed: 26/08/2013 